\title{
Vocational Education and Industrial Relations: Sweden 1910-1975
}

\author{
Tobias Karlsson, Fay Lundh Nilsson \& Anders Nilsson
}

\begin{abstract}
In this article we discuss vocational education in Sweden against the backdrop of the changing nature of industrial relations in the period from ca 1910 to 1975. Drawing upon evidence from official inquiries and case studies of two industries (forest industry and shipbuilding), we show that Sweden in the 1940s and 1950s can be described as a collective skill formation system in the making, where firms, intermediary associations, and the state cooperated around vocational education and training. However, Sweden developed in a very different direction than similar countries. We argue that this remarkable change of trajectory cannot be understood without considering the simultaneous disintegration of the model of industrial relations, along with general changes in the system of education.
\end{abstract}

Keywords • vocational education and training, firms, industrial relations, Sweden, twentieth century

\section{Introduction}

In Sweden, there is a long tradition of studying the history of vocational education and training (hereinafter vocational education) in light of more general changes in the system of education. ${ }^{1}$ Following studies by Lundahl, ${ }^{2}$ Olofsson ${ }^{3}$ and Hellstrand, ${ }^{4}$ we approach the evolution of vocational education from a different perspective, namely that of industrial relations. By "industrial relations," we essentially mean relations between employers and workers in a broad sense. ${ }^{5}$ Although we do not seek to downplay the importance of overall educational reforms, we argue that an industrial relations perspective offers important insights into the development of vocational education. It also allows us to generate new questions concerning the roles of companies and trade unions at different times.

1 Sixten Marklund, Skolsverige 1950-1975, del 1-5 (Stockholm: Liber Utbildningsförlag, 1980-1987); Gunnar Richardson, Svensk utbildningshistoria (Lund: Studentlitteratur, 1st edition, 1977); Hans A. Larsson, Mot bättre vetande: En svensk skolhistoria (Stockholm: SNS Förlag, 2011).

2 Lisbeth Lundahl, Efter svensk modell: LO, SAF och utbildningspolitiken 1944-90 (Umeå: Boréa förlag, 1997).

3 Jonas Olofsson, Svensk yrkesutbildning: Vägval i internationell belysning (Stockholm: SNS Förlag, 2005).

4 Sandra Hellstrand, “Attempting Institutional Change: Swedish Apprenticeship, 1890-1917," Nordic Journal of Educational History 3, no. 2 (2016), 31-53.

5 Bruce E. Kaufman, "The Original Industrial Relations Paradigm: Foundation for Revitalizing the Field," in New Directions in the Study of Work and Employment, ed. Charles J. Whelan (Cheltenham: Elgar, 2008), 31-47.

Tobias Karlsson is Associate Professor at the Department of Economic History, Lund University, Sweden. Email: tobias.karlsson@ekh.lu.se

Fay Lundh Nilsson is Senior Lecturer at the Department of Economic History, Lund University, Sweden. Email:fay.lundh_nilsson@ekh.lu.se

Anders Nilsson is Professor at the Department of Economic History, Lund University, Sweden.

Email: anders.nilsson@ekh.lu.se 
Seen in relation to overall changes in the educational system, with the introduction of unified secondary school in the late 1960s as a major reform, the reason why vocational education in Sweden today is school-based with the state as the important actor but with little involvement of firms appears obvious. ${ }^{6}$ These characteristics are, in the "varieties of capitalism" tradition, classified as a statist skill formation system. ${ }^{7}$ However, in other countries with a statist system, for example France, actors in the labour market hold a fairly weak position and industrial relations are often strained. In Sweden, industrial relations have been characterised by a high degree of collective bargaining and the labour market parties have held a strong position since the early 20th century. In countries with similar labour market characteristics, such as Germany and Denmark, vocational education has evolved into collective skill formation systems in which firms, intermediary associations and the state cooperate. ${ }^{8}$ Thus, in light of industrial relations, the low involvement of Swedish firms is an enigma.

In addition to shifting the focus towards industrial relations, we also shift the level of analysis from top-level policy making to actual practices at the levels of individual industries and firms. In this regard, we are inspired by the research strategy suggested by Peter Hall and Kathleen Thelen, who see firms as crucial actors in institutional change. ${ }^{9}$ For our purpose, however, analysing only firms would be insufficient, since trade unions were strong and active in matters concerning vocational education during the period.

Our aim in this article is to discuss Sweden's transition into a statist skill formation system against the backdrop of the changing nature of industrial relations in the period circa 1910 to 1975 . As seen in the following section, the development of industrial relations in the period of investigation can be divided into two phases: the period of collective agreements (1910-1930) and the Swedish Model (1930-1975). Whereas the first period was characterised by conflicts between trade unions and employers, cooperation prevailed in the latter period. Our central research questions are: What characterised companies' and trade unions' involvement in vocational education in the two periods? How did the transition from conflict to cooperation influence vocational education? Why did Sweden not evolve into a fully-fledged collective skill formation system but take a different path in the 1960s?

To capture development processes at the firm level, we draw chiefly on case studies from two industries: the shipbuilding industry and the forest industry. The latter was a cornerstone in the Swedish economy throughout the 20th century and shipbuilding was a large and expanding industry in 1940-1970. We use Kockums in Malmö as an example of shipbuilding. In the 1950s and 1960s it was one of the biggest shipyards in the world, with a constant need for skilled labour. Regarding the forest industry, we make a distinction between forestry, which was dominated

6 Michael Dobbins and Marius Busemeyer, "Socio-Economic Institutions, Organized Interests and Partisan Politics: The Development of Vocational Education in Denmark and Sweden," Socio-Economic Review 13, no. 2 (2015), 259-84.

7 Marius Busemeyer and Christine Trampusch, eds., The Political Economy of Collective Skill Formation (Oxford: Oxford University Press, 2012).

8 Busemeyer and Trampusch (2012).

9 Peter Hall and Kathleen Thelen, "Institutional Change in Varieties of Capitalism," Socio-Economic Review 7, no. 1 (2009), 7-34. 
by big businesses, and the sawmill industry, with firms of different sizes. These cases are used in a discussion of the economic and institutional preconditions for firms to organise vocational education. In shipbuilding and forestry we find examples of company schools in the 1940s and 1950s and document the origins and characteristics of these schools, as well as how they were eventually dismantled. In the sawmill industry we find no equivalent development.

There is one important limitation in this paper: relatively little attention is paid to crafts. This is because they played a comparatively minor role during the period of investigation. In the previous decades, about 1890-1910, crafts had been very active, but unsuccessful, in trying to promote apprenticeship legislation. ${ }^{10}$

\section{Industrial relations in Sweden: an overview}

Theoretically, industrial relations - in a wider sense - and vocational education are intertwined in various ways. The influences between the two may go in both directions, from industrial relations to vocational education and vice versa. In this paper, we are particularly interested in the former aspect: how the relationships between employers and organised workers, at various levels, influence skill formation. Influence may be direct or indirect. A direct influence appears when agreements between labour market parties regulate education. Here, we may observe a conflict of interests, as trade unions have traditionally sought regulations as a way of restricting labour supply to protect jobs and wages for skilled workers. ${ }^{11}$ An indirect influence appears when labour market parties are involved in the design of legislation. ${ }^{12}$ Indirect influences may also appear more or less unintentionally, with agreements on wages, working hours, employment protection and other issues having implications for vocational education. The standard account of apprenticeship is a case in point. ${ }^{13}$ It stipulates that wages are higher than apprentices' productivity at the beginning of the contract and lower towards the end. The employer uses deferred compensation to recoup the initial investment in training. A compressed wage structure, which may be the result of a highly centralised and standardised system of industrial relations, may restrict employers' opportunities to apply classical apprenticeship contracts. The wage system also influences the incentives of individual workers to assist in the training of young workers. If paid by the piece, workers are probably less interested in instructing newcomers than if paid by the hour. In a piece rate regime, it may therefore be necessary to have specialised instructors and a more school-type organisation of training. Workers' incentives to assist in training is also influenced by their degree of employment protection. ${ }^{14}$ Senior workers without protection are unlikely to train young workers since that could mean future unemployment.

During the 20th century, the Swedish system of industrial relations underwent substantial changes, corresponding to long waves in the country's economic devel-

10 Hellstrand (2016).

11 Sidney Webb and Beatrice Webb, Industrial Democracy (London: Longmans, Green and Co., 1902), 453.

12 Cf. Hellstrand (2016).

13 Patrick Wallis "Apprenticeship and Training in Premodern England," Journal of Economic History 68, no. 3 (2008), 832-61.

14 Lorne Carmichael, "Does Rising Productivity Explain Seniority Rules for Layoffs?” American Economic Review 73, no. 5 (1983), 1127-32. 
opment. ${ }^{15}$ Three distinct periods may be discerned: the period of collective agreements (1890-1930), the Swedish Model (1930-1975) and the period of decentralisation and flexibility (1975 to the present). This section, which presents the general features of industrial relations, serves as a backdrop for the following sections in which we look closer at vocational education.

The period of collective agreements was preceded by liberal reforms of trade and industry that paved the way for the formation of trade unions. The Swedish Confederation of Labour (Landsorganisationen, LO), founded in 1898, adopted the principle of industrial unionism, which came to be a characterising feature of the Swedish labour market throughout the twentieth century and beyond. Another characterising feature that originated in the years around 1900 was a high degree of organisation among employers. The Swedish Employers' Confederation (Svenska arbetsgivareföreningen, $\mathrm{SAF}$ ) came to be the biggest employer organisation. ${ }^{16}$

Conflicts between the labour market parties were frequent in the decades around 1900, but from a comparative perspective Swedish politicians left conditions in the labour market relatively untouched. The non-intervention policy produced fertile soil for regulation through collective agreements, at times with national coverage. As early as 1908/1909, nearly half of all workers in the manufacturing sector were covered by collective agreements. ${ }^{17}$ Over time the share covered increased and agreements with national coverage also became increasingly important, although there were temporary fluctuations and considerable differences between industries and trades. The role of employer organisations in the expansion of the system of collective agreements was important. Instead of trying to differentiate labour contracts, as was the case in the United States, Swedish employers strived to standardise terms of employment to a great extent. ${ }^{18}$

The breakthrough in collective agreements coincided with the spread of ideas related to scientific management-initially in the form of time studies and performance-based pay. In contrast to its counterparts in many other countries, the Swedish labour movement embraced rationalisation. In Sweden, scientific management was associated with a transition towards more peaceful conditions in the labour market. This is often explained by the strength of the Social Democratic party, which seized power in 1932, as well as the strong links between the party and the LO. ${ }^{19}$ Moreover, threats of pro-labour legislation are also thought to have induced the SAF to sit at the negotiating table, which resulted in the path-breaking Saltsjöbaden Treaty of 1938 .

The treaty formed the basic rules for the labour market until the 1970s. Essentially, the treaty was a compromise in which the LO accepted rationalisation measures in return for improved real wages. The spirit of mutual understanding was further manifested in a number of separate agreements in the following decades. The view

15 Christer Lundh, Spelets regler: Institutioner och lönebildning på den svenska arbetsmarknaden 18502010 (Stockholm: SNS, 2010).

16 Lundh (2010).

17 Ibid., 125.

18 Peter A. Swenson, Capitalists Against Markets: The Making of Labor Markets and Welfare States in the United States and Sweden (New York: Oxford University Press, 2002).

19 Lundh (2010). 
of the labour market as a separate sphere, in which conditions should be governed by the parties involved, came to be a persistent pillar of the Swedish Model. ${ }^{20}$ Another characterising feature of this period, particularly from the late 1950s, was the increasing centralisation and coordination of wage negotiations with the LO's socalled solidarity wage policy as a central ingredient. Centralisation and coordination were part of a wider programme of macroeconomic management, formulated by the economists Gösta Rehn and Rudolf Meidner. ${ }^{21}$ The programme carried an optimistic view concerning the opportunities of technological change and rationalisation, but also raised serious concerns about the over-heating in the labour market after World War II. To combine high employment, sustained economic growth, low inflation and the fair distribution of income, Rehn and Meidner suggested that the LO should ignore the financial strength of industries and firms when formulating wage demands and instead consider only the nature of jobs and qualifications. Jobs of the same nature and with similar qualifications should have the same level of pay. In that way, inefficient industries and firms would be pushed out of business, which would lead to a more efficient allocation of resources. The state was supposed to offer redundant workers retraining and help them to move geographically to growing regions and industries.

The Swedish Model of industrial relations appeared in full bloom in the latter half of the 1950s. About a decade later, the compromise between capital and labour began to crack. ${ }^{22}$ Worker discontent with far-reaching rationalisations and profits was manifested in more radical demands from the labour movement regarding labour market legislation. In the same period, more fundamental changes were also taking place. Global competition in commodity markets became fiercer and some of the traditional Swedish manufacturing industries collapsed, whereas employment in the service sector, including the public sector, increased in importance. Meanwhile, technological advances opened up new opportunities to organise production. Against this background, employers demanded more flexibility in labour utilisation. Such demands were hard to reconcile in a system of centralised and coordinated collective agreements. Instead there was a general move towards increased decentralisation and the tailoring of employment terms that would fit the needs of individual firms.

\section{Training in firms supplemented by part-time schooling (1910-1930s)}

In the decades after 1900 various indicators suggest that the demand for skills increased in the labour market. The skill premium for skilled workers in the mechanical engineering industry had been increasing for about ten years in $1900^{23}$ and there are qualitative statements of a deficit of skilled workers in Government Official In-

20 Axel Adlercreutz, Kollektivavtalet: Studier över dess tillkomsthistoria (Lund: Gleerup, 1954); Svante Nycander, Makten över arbetsmarknaden: Ett perspektiv på Sveriges 1900-tal (Stockholm: SNS förlag, 2002).

21 Landsorganisationen i Sverige, Organisationskommittén, Fackföreningsrörelsen och den fulla sysselsättningen (Stockholm: s.n., 1951).

22 Lundh (2010).

23 Fay Lundh Nilsson, Lönande lärande: Teknologisk förändring, yrkesskicklighet och lön i svensk verkstadsindustri omkring 1900. Lund Studies in Economic History 40 (Stockholm: Almqvist \& Wiksell, 2007). 
quiries 1912 and $1924 .{ }^{24}$ To alleviate the situation, more and better vocational education was called for and there seems to have been a general consensus on how to improve the situation, formulated in 1912 in the following way:

\begin{abstract}
Vocational education is mainly practical and should take place primarily through professional work in workshops under the guidance of a master or employer. The theoretical knowledge that a skilled worker needs as a supplement should be provided in specially designed vocational schools where instruction is restricted to a moderate number of hours, not to encroach on the hours spent in work. ${ }^{25}$
\end{abstract}

\title{
Apprenticeship agreements
}

The main obstacle to a proper skill formation system was the unstable relation between apprentices and employers. There were frequent complaints about employers who used "apprentices" as cheap labour without providing them with any training, as well as about apprentices who left their employer without fulfilling their obligations, leaving the employer with training costs but without being able to reap any benefits. ${ }^{26} \mathrm{~A}$ few countries had tried to solve this problem by introducing apprenticeship legislation. By the turn of the century, Austria (1883/1907), Denmark (1889) and Germany (1897) had introduced legislation that guaranteed training during the apprenticeship period at the same time as preventing apprentices from leaving until the end of that period. ${ }^{27}$ These measures had been taken mainly to protect handicrafts and in Sweden, too, handicraft organisations had demanded similar legislation. In addition, some of the collective agreements that were concluded from about 1900 onwards included stipulations on apprenticeships. In the early years, however, apprenticeship agreements were common only in a few industries and furthermore many agreements covered only some aspects. For example, several agreements included only stipulations on apprentices' pay, whereas others could be quite detailed also in matters concerning the training necessary to guarantee proper training in the workplace. $^{28}$

Information on apprenticeships in collective agreements at a general level was collected by the National Board of Health and Welfare (Socialstyrelsen). The Board published a detailed cross-sectional survey of the content of agreements concluded in 1907/1908 and a second survey in 1920. For the period in between, the Board published annual reports of the number of new agreements. The 1907/1908 survey reveals that agreements on apprenticeship were present in several industries and that 8,596 apprentices - corresponding to about 3 per cent of all workers covered by collective agreements at the time-were accounted for in these agreements. Two thirds of the apprentices were covered in collective agreements with explicit apprenticeship

24 Underdånigt utlåtande och förslag till den lägre tekniska undervisningens ordnande (Örebro: Länstidningens tryckeri, 1912); SOU 1924:41, Utredning med förslag till lag om lärlingsväsendet i vissa yrken (Stockholm: Norstedt \& söner, 1924).

25 Underdånigt utlåtande (1912), author's translation.

26 Tom Söderberg, Hantverkarna i genombrottsskedet 1870-1920 (Stockholm: Haglund \& Ericson, 1965).

27 Utlåtande och förslag till den lägre tekniska undervisningens ordnande (Örebro: Länstidningens tryckeri, 1912).

28 Kollektivaftal angående arbets- och löneförhållandena i Sverige 1907/1908, 1. Redogörelse för kollektivaftalens utbredning och hufvudsakliga innehåll (Stockholm: 1910), 239-40. 
stipulations regarding, for example, wages or length of apprenticeship. The remaining third underwent apprenticeship training according to what was called "the customs in the industry." ${ }^{29}$ Explicit apprenticeship stipulations were concentrated on certain handicrafts, such as bakeries and harness-makers, and to three industries, tobacco, printing and (parts of) paper manufacturing, whereas customary training was prevalent in mechanical engineering and glass foundries, among others.

By the time of the second survey in 1920, the system was only marginally more widespread. The number of collective agreements with stipulations on apprenticeship was virtually the same as in 1908 (315 and 316, respectively) and the number of workers in industries with such agreements in 1920 amounted to $41,000^{30}$ versus 36,000 workers in $1908 .{ }^{31}$ In addition, it should be noted that the numbers of workers in industries with collective agreements only corresponded to about 25 per cent of all workers in manufacturing industries and handicrafts.

Our knowledge of the contents of apprenticeship stipulations in collective agreements is limited. A reasonable assumption is that the relative influence of employers and trade unions over apprenticeship training was related to the parties' access to various power resources and shifted according to business cycles. Whereas employers typically tried to keep full prerogative over apprenticeship training, including the employment terms of workers in training, trade unions sought to restrict the number of apprentices in relation to trained workers and impose other measures, such as the maximum extent of the apprenticeship period, to guarantee the quality of training. ${ }^{32}$

\section{Vocational schools}

In addition to practical training in workshops, apprentices and other young workers were offered the opportunity to supplement their vocational education in technical evening and Sunday schools (tekniska afton-och söndagsskolor). Such schools had existed for a long time and the number of pupils amounted to about 10,000 in the academic year 1909/1910. ${ }^{33}$ However, only two thirds of them were employed in manufacturing industries or in handicrafts. ${ }^{34}$ Among young people of what was called "apprenticeship age," that is 14-17 years old, it was estimated that only about 5 per cent of the employed participated in technical evening and Sunday schools. ${ }^{35}$

In 1918, a reform act was launched which proposed that vocational schools would become supervised and partly funded by the state, but would be operated by municipalities and to some extent by private actors. ${ }^{36}$ Instruction took place in the afternoons and evenings on a part-time basis in so-called apprentice schools

29 Kollektivavtal (1910), 239.

30 SOU 1924:41. Utredning med förslag till lag om lärlingsväsendet $i$ vissa yrken (Stockholm: Norstedt \& Söner, 1924), Table Q.

31 Kollektivavtal (1910), 239.

32 Berit Bengtsson, Kampen mot \$23: Facklig makt vid anställning och avsked i Sverige före 1940 (Uppsala: Uppsala universitet, 2006).

33 Anders Nilsson, Yrkesutbildningen i Sverige 1850-1910 (Uppsala: Föreningen för svensk undervisningshistoria, 2008), 170-71.

34 Utlåtande och förslag till den lägre tekniska undervisningens ordnande (1912), 38.

35 Utlåtande och förslag till den lägre tekniska undervisningens ordnande (1912), part II, 112.

36 Anders Hedman, I nationens och det praktiska livets tjänst: Det svenska yrkesskolesystemets tillkomst och utveckling 1918 till 1940 (Umeå: Umeå universitet, 2001). 
(lärlingsskolor). These schools were mainly intended for young people of "apprenticeship age," but in 1921 only 4,500 of that age group participated in the apprentice schools. ${ }^{37}$ Even though the number of young students increased subsequently, vocational schools gradually came to attract adults rather than young people. By the mid-1930s, adults outnumbered youngsters in the vocational schools and their predominance continued well into the early 1960 s. $^{38}$

For young workers (under 18 years of age) in manufacturing industries and in handicrafts, vocational schools remained a marginal phenomenon. In 1921, these sectors employed around 63,000 young people, ${ }^{39}$ which implies that the proportion of this age group in vocational schools had increased marginally from about 5 to 7 per cent between 1907 and 1921. It is a reasonable conclusion that the training of skilled workers did not function very well around 1920. The apprenticeship system was not well defined and could be misused and the existing supplement with vocational education in apprentice schools was only taken advantage of by a small number of apprentices.

\section{The failure to introduce apprenticeship legislation}

When the reform of vocational education was launched in 1918, it was assumed that the school system would be supplemented with apprenticeship legislation to ensure proper training in the workplace. The legislation proposal was motivated by the inadequacy of existing apprenticeship training. The existing apprenticeship agreements were considered to be insufficiently binding, leaving too much discretion to the employer's commitment to learning and making it too easy for the apprentice to leave the employer before the end of an apprenticeship. The proposal suggested that a binding contract should be made between the employer and the apprentice, with legal sanctions if any one of them violated the contract. The contract included obligations for the employer to train the apprentice fully and-where possible-make sure that the apprentice attended a vocational school. ${ }^{40}$

This was not the first time apprenticeship legislation had been on the agenda. Between 1893 and 1913 six drafts, proposals and enquiry reports were produced. To a varying degree, they had involved Parliament, government agencies, craft organisations, industrial employers' federations and trade unions. In the initial proposals, apprenticeship legislation was called for only in crafts, but eventually employers in manufacturing industries became interested in legislation that would also encompass industrial enterprises. However, the craft employers and the industrial employers had very different views on the contents of an apprenticeship law and in addition the trade unions had very different demands from the employers. The in-depth study of this period by Hellstrand concludes that although all interest groups were in principle in favour of legislation, the disagreements concerning the content were so strong that a formal proposition never reached Parliament. ${ }^{41}$

37 SCB Promemorior 1984:2, Elever i skolor för yrkesutbildning 1844-1970 (Örebro: Statistiska centralbyrån, 1984), Table 7b; Yrkesundervisningen: Åren 1921-1922 (Stockholm: Kungl. Skolöverstyrelsen 1923), Table 32.

38 Anders Nilsson, “The Unknown Story: Vocational Education for Adults in Sweden 1918-1968," History of Education 43, no. 5 (2014), 615-34.

39 Statistisk Årsbok 1926 (Stockholm: P.A. Norstedt \& söner, 1926), Tables 96 and 100.

40 SOU 1924:41 (1924).

41 Hellstrand (2016). 
When the new proposal was put forward in the early 1920s, resistance was much fiercer. The trade unions feared that legislation could keep wages low for young workers and that the apprentices would become too dependent on the employer. The employers opposed those parts that would give the state influence over the relation between apprentices and employers and considered the proposal too costly. ${ }^{42}$ Both groups also pointed to the existing apprenticeship agreements as a satisfactory solution. Neither the employers not the trade unions wanted government interference in what they saw as a labour market issue. Even the Swedish Handicraft Association, which in principle was in favour of apprenticeship legislation, raised many objections to the proposal. ${ }^{43}$ As a result, apprenticeship legislation was not put in place in the early 1920s and a second attempt to introduce it in the mid-1930s was also met with fierce resistance from trade unions and employers. ${ }^{44}$ Since then, apprenticeship legislation has not been on the political agenda in Sweden.

\section{The rise of an embryonic collective skill formation system (1930s-1960s)}

In the 1930s - and gaining increasing momentum in the 1950s-the Swedish economy entered a new phase of change, with new products and methods transforming activities in most parts of the economy. ${ }^{45}$ The high level of youth unemployment in the 1930 s led to an increased interest in vocational education. ${ }^{46}$ Employers and the trade unions advocated an expansion of vocational education in areas in which there was demand for labour.

\section{Towards a collective skill formation system}

In 1943, matters concerning vocational education were detached from the central Board of Education and entrusted to a new central authority, the National Board for Vocational Education. On this Board, the labour market parties were strongly represented. By creating a tripartite board for vocational education, an important foundation was laid for a collective skill formation system. A few months later, in 1944, a further brick was laid when the central labour market parties founded the Vocational Council of the Labour Market (Arbetsmarknadens yrkesråd), which played an active role in the 1940s, 1950s and 1960s. ${ }^{47}$ The council promoted several activities to advance vocational education, including conferences, pamphlets and career guidance. To organise these activities, Apprenticeship Committees were set up in several industries. On these committees, as in the central Vocational Council, the labour market parties had equal representation. Seven committees were set up almost immediately and by 1952 , their number had increased to twelve. ${ }^{48}$

The Vocational Council advocated the organisation of training in workshops, reg-

42 Hedman (2001).

43 Hantverkarorganisationens kongresser: Anteckningar från SHO årsmöte (1925), Arkivbeteckning NAD: SE/RA/730338/A3.

44 Anders Nilsson, “Lärlingsutbildning: Ett alternativ i yrkesutbildningen 1940-1970," in Yrkesutbildningens formering i Sverige 1940-1975, ed. Peter Håkansson and Anders Nilsson (Lund: Nordic Academic Press, 2013), 87-120.

45 Lennart Schön, Sweden's Road to Modernity (Stockholm: SNS Förlag, 2010).

46 Peter Håkansson, Ungdomsarbetslöshet: Om övergångsregimer, institutionell förändring och socialt kapital (Lund: Lunds universitet, 2011).

47 Olofsson (2005).

48 Olofsson (2005). 
ulated by collective agreements and supplemented by theoretical education in vocational schools. ${ }^{49}$ The agreements should be industry-specific to allow for, among other things, varying length of apprenticeships. Despite this flexibility, it soon became apparent that it was not followed by all companies. In reality, different strategies were followed. A fairly large number of companies launched apprenticeship programmes along the lines proposed by the Vocational Council in the 1940s and early 1950s. By 1950, it was estimated that systematic vocational training was taking place in almost 1,200 companies. The scale was generally small. Around 1950, a large enterprise (with more than 500 employed) admitted on average only 8 new apprentices annually and in smaller enterprises that figure was even lower. ${ }^{50} \mathrm{~A}$ limited number of large companies gradually adopted a second strategy by operating industrial schools with substantially more students/apprentices. This strategy was reinforced in the mid-1950s when generous state subsidies became available. The third strategy was the most common. Most companies and often whole industries did not engage in vocational education. In what follows, we look at one company and two industries to investigate the different strategies.

\section{Company-based apprenticeship}

The shipyard Kockums started an apprenticeship programme in 1943, partly to cope with an acute and seemingly persistent shortage of skilled workers. The training was regulated through an apprenticeship contract based on a template issued jointly by the Swedish Engineering Employers' Association and the Metal Industry Workers' Union. The contract stated, among other things, that after a trial period of six months, the apprentice was entitled to complete training in an occupation. It also stipulated terms of payment and the apprentice's obligations during the training period. ${ }^{51}$ Interviews with people who were accepted as apprentices in 1955 and 1966, respectively, indicate that the structure of training was fairly constant over the years. The first year of training was common to all participants. It included practical courses in basic company skills, such as welding, cutting and filing, as well as theoretical courses in, among other things, knowledge of materials, industrial relations laws and basic book keeping. During the first year, about half the working day was spent in school and the rest of the day the apprentices did practical work, in which the tasks were quite simple and even monotonous. During the second year, the apprentices selected a specific occupation, for example welding. Practical training in this occupation took place in the workshop under the supervision of an experienced worker. The theoretical courses were limited to about one afternoon per week. In the third year, theoretical courses were optional and all training was performed in the workshop. ${ }^{52}$ In the 1940 s, the programme was on a small scale and in reality limited to

49 Arbetsmarknadsorganisationernas yrkesutbildningskommitté (AY), Betänkande med förslag till åtgärder för lärlingsutbildningens främjande (Stockholm: s.n., 1944).

50 SOU 1954:11, Yrkesutbildningen (Stockholm: Ivar Häggströms boktryckeri AB, 1954).

51 Utbildningsverksamheten vid Kockums, 1943-1957, F20:3, Kockums Mekaniska Verkstads AB, Malmö Stadsarkiv, Företagsarkiv, Handlingar gällande verkstadsskolan samt elevföreningen. Arkivbeteckning NAD: SE/MSA/00429/F/F20.

52 Interviews with Rauno Eberlund, ship construction apprentice 1966-1969, interviewed 30 March 2015; Bengt Persson, electrician's apprentice 1955-1958, interviewed 6 March 2013; Åke Sandström, electrician's apprentice 1966-1969, interviewed 30 March 2015. 
welding for ship construction workers, with 12 to 19 apprentices accepted annually. ${ }^{53}$

In the forestry industry, where the piece rate system dominated, there was no incentive for companies to take an interest in basic forestry training since each woodman owned his tools and bad tool management and work techniques mainly had consequences for the individual. From the companies' point of view the woodman was replaceable as long as there was plenty of labour. However, the Forestry Workers' Union started to engage in educational issues at the end of the 1930s. At this point in time, youth unemployment was high, especially in counties where the forest industry was an important activity and where rationalisation in sawmilling and the pulp industry had led to fewer jobs. A series of articles in the Forestry Workers' Journal discussed the expansion of vocational education in areas where there was demand for labour as a solution to the problem. However, it is worth noting that the union's interest in a specific vocational education for woodmen was not yet on the agenda. ${ }^{54}$ At the beginning of the 1940s, the union demanded that forestry work become a profession and not remain temporary employment with insecure subsistence. When, at the same time, a shortage of labour in the forest industry arose, the issue of training for woodmen also attracted attention among employers. ${ }^{55}$

In 1943, one of the largest forest companies, Mo och Domsjö, initiated the first company-based course for vocational education in the forest industry. The training programme (partly inspired by a German model for training of woodmen) alternated theoretical school periods with periods of practical training. The students were aged 16-20 and mainly recruited from families linked to the company. Most of them became employees after completing the training period. During the years 1943-1956, the length of the courses amounted to 10-14 weeks. During these 14 years around 260 students attended the courses. Mo och Domsjö benefited from the investment in vocational education by getting more reliable and loyal workers than those who were recruited from outside. ${ }^{56}$

A state-sponsored one-year apprenticeship course for students, also aged 16-20, started in 1956 and was extended to a two-year course in 1959. The theoretical part of the training was handled by the Forestry Board (Skogsstyrelsen) and the internship would be accomplished in close collaboration with the National Forest Enterprise (Domänverket) and forestry companies. The course became popular and engaged around 1,100-1,300 pupils annually. Some of the largest forestry companies, such as Mo och Domsjö and Svenska Cellulosa AB (SCA), wholly or partially organised their own apprenticeship courses, thus continuing their investment in education until the late 1960 s. $^{57}$

In spite of the efforts of the Vocational Council, Apprentice Committees and individual companies, the number of apprentices in Sweden fell from about 20,000 in

53 Etsuo Yokoyama and Anders Nilsson, "Company-Based Vocational Education and Training: Case Studies of Shipbuilding Industries in Japan and Sweden," Essays in Economic \& Business History 34 (2016), 136-64.

54 Skogsindustriarbetaren (Gävle, 1939), no. 23/24; Skogsindustriarbetaren (Gävle, 1939), no. 34; Skogsindustriarbetaren (Gävle 1940), no. 2.

55 Kungliga Skogsstyrelsen, Det enskilda skogsbruket (Stockholm: Kungl. Skogsstyrelsen,1943); Skogsindustriarbetaren (Gävle 1943), no. 25/26.

56 Sven-Ingvar Sjöstedt, Skogsyrkesutbildning i Sverige (Karlshamn: Lagerblads, 1975), 48-50.

57 Ibid., 55-57, 123-124. 
1940 to 15,000 in 1950, even though the workforce in manufacturing industries was growing rapidly. ${ }^{58}$ Even mechanical engineering, which was seen as a forerunner in issues concerning vocational education, ${ }^{59}$ experienced difficulties. In 1946, the number of apprentices was about the same as it had been in 1939 (about 4,000), but in relation to the number of skilled workers the percentage had decreased from 15 to 10 per cent. ${ }^{60}$

\section{Industrial schools}

During the 1950s, vocational education was widely discussed and there was strong public interest in improving skills. The radical rationalisation of manufacturing industries had led to new demands on the workforce, including more teamwork and greater demands on the ability to cooperate, which also put new demands on vocational education. ${ }^{61}$ Moreover, the large export-oriented companies found it difficult to meet their skills needs. In its annual report of 1954, Kockums pointed out that "this year, as well as in the previous ones, finding skilled labour is very difficult." ${ }^{62}$ As a response, Kockums expanded its apprenticeship programme from 1951 onwards with new specialisations. The company produced its own curricula for each specialisation and increased the annual intake of apprentices substantially. In doing so, the company was inspired by so-called industrial schools (industriskolor). ${ }^{63}$ In these schools, a firm managed theoretical education as well as practical training. A few industrial schools had existed as far back as the $1920 \mathrm{~s}^{64}$ and their number had increased in the 1940s. In 1955, the Riksdag decided to increase state subsidies to fulltime courses in vocational education, with staggering results. The number of students in such courses increased from about 20,000 in 1955 to 55,000 in 1960. Most of the expansion took place in municipal schools with an emphasis on one- or two-year programmes, but the reform included the possibility for industrial schools to receive state grants, provided they were placed under the supervision of the national Board of Vocational Education. This possibility gave new impetus to industrial schools. At Kockums, the activities in the apprenticeship programme were transformed in 1957 to an industrial school with its own premises. A School Board was appointed, which, in line with the principles in the Saltsjöbaden Treaty, had an equal number of representatives from the workers' organisations and the management. The aim of the school was to give the students (who were employed as apprentices) appropriate vocational education, taking the company's demand for a skilled workforce into consideration, including skilled workers, foremen and supervisors and technicians.

$\overline{58 \text { Nilsson (2013), } 97 .}$

59 AY (1944).

60 Teknikföretagen. F12a, vol. 52. Särskilda utredningar, "Uppgift på antal arbetare, yrkesarbetare resp. lärlingar vid verkstäder anslutna till Sveriges Verkstadsförening åren 1925-1947," Arkivbeteckning NAD: SE/CFN/TKF_1.

61 SOU 1954:11.

62 Årsrapport 1954 i Årsrapporter från utbildningsavdelningen 1952-1966, F20:3, Kockums Mekaniska Verkstads AB, Malmö Stadsarkiv, Företagsarkiv, Handlingar gällande verkstadsskolan samt elevföreningen, Arkivbeteckning NAD: SE/MSA/00429/F/F20.

63 Utbildningsverksamheten vid Kockums.

64 SOU 1939:14, Rationaliseringsutredningens betänkande del II (Stockholm: Isaac Marcus boktryckeri aktiebolag, 1939). 
To achieve this, several types of courses existed. In addition to the apprentice school, the industrial school also ran short courses for older workers, more extensive courses in drawing and for supervisors and occasional courses "when the need arises." ${ }^{65}$

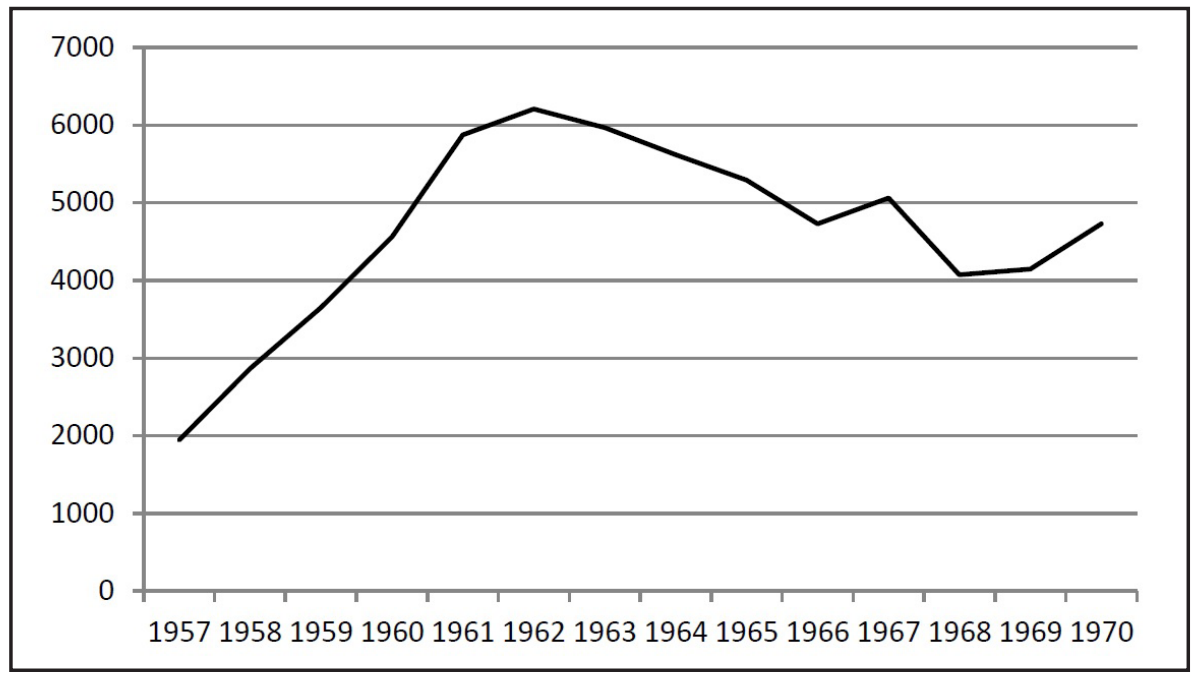

Figure 1. Number of students in industrial schools 1957-1970.

Source: SCB 1984, Table 17 and Statistical Yearbook 1971, Table 358.

During the first years, industrial schools were quite successful and the number of students attending increased three-fold between 1957 and 1962. However, during most of the 1960s, industrial schools faced problems in attracting students (see Figure 1). The Swedish school system was undergoing drastic changes and in that process industrial schools became less popular. The gradual introduction of the nineyear comprehensive school (grundskolan) meant that new educational possibilities emerged. In 1964, the annual report from Kockums stated that "The apprentices that have been hired come from a fairly thinned-out student population and their prognoses are not always the best." ${ }^{\prime \prime 6}$ The academic track in upper secondary school (gymnasiet) became increasingly popular and in Kockums' case, the establishment of the professional school (fackskolan) in 1965 was explicitly reported to be a very strong competitor: "The newly established professional school has considerably more than expected diminished the number of applicants to the school." ${ }^{67}$

In the mid-1950s the training programme at Mo och Domsjö was extended to a two-year apprentice course and two other companies, SCA and Domänverket, started similar courses, the latter entailing five one-year vocational courses for woodmen. With three company schools, the number of apprentices increased, but did not amount to more than about 100 per year. ${ }^{68}$ The number of students suddenly dropped in 1963-1964 following the conclusion by the Labour Market Board that

65 Utbildningsverksamheten vid Kockums.

66 Årsrapport Kockums (1964).

67 Årsrapport Kockums (1965).

68 Skogsyrkesutbildningen i Sverige (1975). 
manpower needs in the forest industry would decrease by 50,000 by 1970 . The course was also criticised for not being able to provide enough qualified supervisors and appropriate tasks for the students/apprentices. The Forestry Training Committee (Skogsbrukets yrkesutbildningsnämnd, SYN ${ }^{69}$ then submitted a proposal arguing that the traditional division between school and practice periods should be replaced with coherent training in special forestry schools. ${ }^{70}$ These changes were gradually implemented.

The academic year 1967/1968 was the last year of the company schools and the apprenticeship courses came to an end in 1971. The late 1960s also meant the end for the so-called continuation school (fortsättningsskolan), focusing on forestry work. This type of school had been established when the forest employers took the initiative to start forestry training for young boys who had just left compulsory elementary school. The continuation school, focusing on forestry work, offered training in counties where the forestry industry was dominant. The training comprised a shared commitment: forestry companies addressed the practical training and school authorities met the costs. The first school started in 1946. After a relatively modest start, interest increased explosively from around 1950. At the end of the 1960s, about 3,500 students had been trained at continuation schools focusing on forestry work. ${ }^{71}$ In an article in Skogsindustriarbetaren in 1947, a forest manager from the large forest company Munksund was interviewed about the cooperation between the company and the school authorities. It is clear that both the union and the employers had come to the same conclusion: forestry work is a profession that requires knowledge, like all other professions, and without skilled woodmen, you cannot implement improvements and rationalisation measures. ${ }^{72}$

\section{Companies and industries not involved in vocational education}

In most small and medium-sized companies, the difficulties in organising formal training at an acceptable cost were considered prohibitive. The traditional way of training young workers, by letting older and more experienced workers demonstrate relevant methods, was considered sufficient by the employers. Unions were in general more active in promoting organised training, as our example from the sawmill industry illustrates.

The union observed the need for education in the early 1940s, when the traditional training of young workers by older and more experienced workers in the workplace ceased to function as before due to streamlining and rationalisation. ${ }^{73}$ When the so-called Norrlandskommittén, a committee that investigated the state of things in northern Sweden, suggested a central vocational school for sawmill workers in 1947, it was apparent that the union and the employers' organisations had quite different ideas about the importance of vocational education. The union, which was in

69 A joint organisation for the forest workers' union, forest owners and employers' organisations.

70 SOU 1965:67, Skoglig yrkesutbildning: Utbildningsmål, utbildningsgång och huvudmannaskap. Betänkande avgivet av skogsbrukets yrkesutbildningskommitté (Stockholm: K.L. Beckmans tryckeri $\mathrm{AB}, 1965)$.

71 Skogsyrkesutbildningen i Sverige (1975).

72 Skogsindustriarbetaren (Gävle, 1947), no. 1.

73 Skogsindustriarbetaren (Gävle, 1943), no. 1. 
favour of education that combined practical and theoretical elements, saw vocational education as an opportunity to give the occupation a higher status and thus an incentive to raise the wage level, which in turn would increase interest among youth for sawmill work. The Sawmill Association (Sågverksförbundet), however, considered that the need for vocational education only concerned a small percentage of workers undertaking specialised tasks, which meant about 10-12 per cent of the workforce (1,500-1,800 workers). The practical training could be done in sawmills, while the theoretical part could take the form of evening courses in the workers' leisure time.${ }^{74}$ If it was in the union's interest to raise the status of the occupation and hence the wages, it was in the employers' interest to keep costs down. These attitudes seem to have been more or less prevalent for decades. When basic forestry education was incorporated into upper secondary school in 1971, the sawmill industry was still without a formal basic vocational education programme. However, the idea of a central sawmill school, which had already been launched in the 1940s, finally became a reality in the mid-1970s, likely due to strong personal engagement among a handful of persons. ${ }^{75}$

The difficulties of the sawmill industry establishing vocational education can partly be explained by the special structure of the industry, with many small and medium sized sawmills. It is clear that there would have been difficulties in organising formal education at an acceptable cost. Another reason is that technological factors played an important role. While woodmen could be trained to handle a chainsaw (provided by the workers themselves) at a relatively low cost, there was a much higher risk of major economic disruption in the sawmill. Yet another factor was that in contrast to the Forestry Training Committee, SYN, the equivalent organisation for the sawmill industry, STYN (Sågverkens och träindustrins yrkesnämnd), never really seemed to play a major role in establishing relevant vocational education for sawmill workers. While the SYN was noticed in the debate, the STYN was conspicuous by its absence.

\section{Towards a statist skill formation system (1960s and 1970s)}

While some large firms initiated their own schools and politicians reformed vocational education, there were simultaneous moves towards further centralisation of the Swedish system of industrial relations, with important long-term implications. Vocational education was not emphasised in the LO programme of 1951, but was mentioned in passing as a way, along with the wage policy and general information activities, through which trade unions could contribute to rationalisation. Rehn and Meidner acknowledged that wage equalisation could reduce the incentives to invest in vocational education, but pointed out that a solidarity wage policy did not exclude wage differentiation according to skill and that the policy should be preceded by ambitious evaluations of jobs before implemented. They also acknowledged that shortage of labour could in principle make people less interested in vocational education, but argued that this was not the case in Sweden, referring to the increasing numbers

\footnotetext{
74 Skogsindustriarbetaren (Gävle 1947), no. 32.

75 Fay Lundh Nilsson, “Sågverksindustrin och utbildningsfrågorna," in Sågad skog för välstånd: Den svenska sågverksindustrins historia 1850-2010, ed. Ronny Pettersson (Stockholm: Kungliga Skogsoch Lantbruksakademien, 2015), 407-52.
} 
of young people enrolled in vocational education. ${ }^{76}$ If there was a problem, it was caused by a shortage of resources in the form of facilities and teachers.

Although the solidarity wage policy is an often highlighted feature of the Swedish Model of industrial relations, the practical implications for vocational education are not well understood. A working hypothesis may be that the solidarity wage policy, when implemented in the 1960s and 1970s, restricted the scope for firms to use wages to induce investments in training and long-lasting employment relationships, at least for the blue-collar segment of the labour market. The principle of "equal pay for equal work" meant that firms could not reward seniority to the same extent as before. When differences in earnings between young and senior workers were reduced, there were weaker incentives for young people to enter traditional apprenticeship contracts, which typically involved cost sharing between apprentice and employer and included a proportion of deferred payment.

Moreover, the LO programme from 1951 also paved the way for increased emphasis on theoretical education generally and a decreased role of firms in the overall system of skill formation. This was not an explicit idea in the original programme but was articulated somewhat later. In 1961, the LO, for example, stated that "extended general primary education" would facilitate occupational mobility. ${ }^{77}$ The formulation provided direct support for the ongoing educational reforms that were under way.

The new nine-year comprehensive school (enhetsskolan, later on grundskolan) was to some extent an answer to these new needs with its three programmes, including an occupational programme called 9y, within which the pupils could choose a vocational programme during their last school year. The idea was to prepare the pupils for an occupation: teaching would be mainly vocational and only about a third of the instruction would be devoted to general subjects. ${ }^{78}$ In this and related reforms, the labour market parties managed to take a joint stand, but in spite of the organised collaboration between the labour market parties, some of the old conflicts concerning vocational education lingered underneath the surface. Whereas employer representatives wanted vocational education to be specific and adjusted to company needs, union representatives favoured more theoretical and general content. In the 1960s, when a new system for vocational education was discussed, these differences surfaced. The SAF and the Swedish Handicraft Association resisted the changes but the trade unions were, in general, strong supporters. ${ }^{79}$

In 1968 the Parliament adopted an organisationally coherent upper secondary school (launched in 1971) that would last for the next 25 years despite many attempts at reform. ${ }^{80}$ Vocational education disappeared from compulsory schooling and the separate vocational schools were integrated with upper secondary school, in

76 Landsorganisationen i Sverige, Organisationskommittén, Fackföreningsrörelsen och den fulla sysselsättningen (Stockholm: s.n., 1951).

77 Landsorganisationen i Sverige, Strukturutredningen, Samordnad näringspolitik (Stockholm: LO, 1961), 150.

78 SCB Promemorior 1974:5, Elever i obligatoriska skolor 1847-1962 (Stockholm: Statistiska centralbyrån, 1974) 5 .

79 Lundahl (1997); Nilsson (2013).

80 Lisbeth Lundahl, "Skilda framtidsvägar: Perspektiv på det tidiga 2000-talets gymnasiereform," Utbildning \& Demokrati 17, no. 1 (2008), 29-51. 
which several two-year vocational programmes were started. Municipalities became the responsible authorities. The combination of strained industrial relations and a strong political will to promote a school-based system for vocational education in the late 1960s and early 1970s drastically diminished the possibilities for employers and trade unions to participate actively in vocational education. With few exceptions, the remains of the apprenticeship system, including most firm-based vocational schools, were dismantled in the early 1970s and the active participation of employers' and trade unions' representatives on vocational school councils came to an end in most places.

In hindsight, the importance of the reform in 1968 for the transition into a statist skill formation system may appear obvious. Yet, during the preparatory stage the reform did not seem to be very radical since it was underlined in the political directives that it would become necessary to use the industries' resources to an increasing degree in the new skill formation system. ${ }^{81}$ Some apprenticeship committees were also strongly involved in the transition (for example SYN, the committee for the forest industry) and the employers pointed to the importance of further training. ${ }^{82}$ To some extent, this was met by the introduction of a very large number of "special courses" in upper secondary school. Possibly, the collective features of the Swedish skill formation systems could have survived-and even flourished-after the integration of secondary schooling. As pointed out by Busemeyer and Trampusch ${ }^{83}$ and seen in countries such as the Netherlands, Denmark and Austria, a collective skill formation system may also include substantial elements of school-based vocational education. However, during the late 1960s and early 1970s, the whole Swedish Model of industrial relations was shaken and began to disintegrate. The disintegration of collaboration between business and labour in the area of vocational education may be seen as an additional aspect of that development.

\section{Concluding discussion}

In this article we have approached the history of vocational education in Sweden from a different angle to that usually adopted. Instead of primarily viewing changes in vocational education as a result of changes in the overall system of education, we have highlighted the importance of industrial relations for understanding the character of vocational education from around 1910 to the mid-1970s.

We have posed three central research questions. The first is straightforward: What characterised companies' and trade unions' involvement in vocational education before and after the emergence of the Swedish Model in the 1930s? As we have demonstrated, it was difficult to put a coherent skill formation system in place up to the late 1930s. Dobbins and Busemeyer ${ }^{84}$ argue that the path to a statist model was initialised during this period, but as we have demonstrated, public involvement in vocational education was limited. Most vocational education took place in firms and

81 SOU 1966:3, Yrkesutbildningen: Huvudbetänkande från yrkesutbildningsberedningen (Stockholm: Håkan Ohlssons boktryckeri, 1966), 24.

82 Skogliga gymnasieutbildningen 1970-talet, 1966-1995, F1:3, Skogsbrukets yrkesutbildningsnämnd (SYN), Centrum för näringslivshistoria. Arkivbeteckning NAD: SE/CFN/SLA_26-1.

83 Busemeyer and Trampusch (2012).

84 Dobbins and Busemeyer (2015). 
was predominantly practical, but it did not enjoy a high priority. Collective agreements became increasingly common in the labour market from the 1910s, but only about one fourth of all workers in industry and handicrafts were covered by agreements that included apprenticeship regulations in broad terms. These regulations were complemented by either individual contracts or implicit understandings on the length, content and conditions of training in the workplace. The establishment of the system of collective agreements hardly solved the fundamental problems of vocational education. Apprenticeship legislation could have made a difference, but from the 1920s onwards the trade unions and employers were united in their resistance to it. From a skill formation perspective, this fact may appear odd, but from the perspective of industrial relations, the non-adoption of apprenticeship legislation fits in a more general pattern, according to which firms and unions tried to defend their independence from political intervention.

In the decades following the 1930s, we identify three basic strategies among firms with regard to vocational training: (1) small-scale apprenticeship training, (2) industrial schools and (3) no systematic training arrangements. In the case of shipbuilding (Kockums), we document a transformation from a small-scale programme to a more fully-fledged industrial school in the 1950s. In the case of forestry, we document a rising interest in vocational education in the early 1940s, leading one of the largest firms to offer formal courses for woodmen in the making. This programme was expanded in the 1950s and inspired two other large firms to establish similar courses. However, in the 1960s the industrial schools faced difficulties to attract students and were eventually closed down. Although we have documented significant examples of systematic firm involvement in vocational education, most firms were probably passive in this respect. In the sawmill industry we see how the traditional way of having older workers serve as role models for younger workers prevailed in the 1950s and 1960s, despite union demands for more systematic training.

Our second question concerned how the transition from conflict to cooperation in the labour market influenced vocational education. Here, we may conclude that cooperation between employer organisations and trade unions increased markedly at the national level from the late 1930s onwards. In addition, the state became more involved in skill formation. These processes brought about major changes in vocational education, but the outcome was, as we have shown, different across industries and firms. Numerous companies, including our cases of Kockums and the forest companies, initiated small-scale apprenticeship programmes. Seen from the perspective of industrial relations, this strategy is well in line with the spirit of mutual understanding that was codified in the Saltsjöbaden Treaty of 1938. The transformation of such programmes into formal courses and schools fits less well in the established view of the Swedish Model. At the same time as employer organisations and union federations were seeking more "top-down" solutions, for example concerning wage formation, some large firms were seeking individual solutions in the field of vocational education. Yet, in firms that adopted either of these strategies (apprentice training or schools), relations between employers and local unions in terms of vocational education were generally harmonious. Both parties acknowledged the need for training, low pay for apprentices and substantially higher wages for skilled workers. In these sectors of the economy, the skill formation system was clearly develop- 
ing towards a collective model with firms and trade unions as strong actors. ${ }^{85}$ Most companies, however, were not involved in vocational education and local unions and employers often had conflicting views on training. In the 1940s and 1950s unions tried-mostly in vain - to initiate training programmes in these companies, as our example from the sawmill industry shows. These sectors of the economy paved the way for a completely different direction concerning the Swedish skill formation system. An interesting question for further research is to look closer at how companies that did not invest in vocational education satisfied their demand for skilled workers.

Present-day Sweden is often characterised as a clear example of a statist skill formation system country, with little involvement of firms in vocational education. In the skill formation system literature, the 1960s and 1970s are considered to be a critical juncture during which existing systems could be modified, strengthened, or transformed. ${ }^{86}$ In this period, political processes, the transformation of the economic structure and changing power relations between capital and labour set the stage for renegotiation of the skill system. In most cases, the outcome was a strengthening of the existing system, but in Sweden a radical transformation took place. In fact, the country is one of the few examples where the critical juncture in the 1960s brought about such a change. The inclusion of initial vocational education integrated within upper secondary school meant that the skill formation system in Sweden acquired the characteristics of a statist system. It was an almost complete transition from an embryonic collective system within a short period of time.

This brings us to the third research question: Why did Sweden not evolve into a fully-fledged collective skill formation system, but instead followed a different path in the 1960s? Previous research stresses that the reforms in vocational education were part of an overall reform agenda in the 1950s and 1960s that included all education at the primary and secondary levels. That interpretation contains an element of truth, but we argue that this transfer was made possible for two other reasons. One is that most firms did not participate actively in vocational education and as a consequence, school-based alternatives became more attractive. The other reason, at a more fundamental level, was that the changing nature of industrial relations had profound repercussions for the economic and institutional preconditions for firms to participate in vocational education; from the system of collective agreements in the first half of the 20th century, to the highly coordinated and centralised model of industrial relations in the 1950s and 1960s and the first signs of the same model's dissolution around 1970. And this is not the only aspect in which the Swedish experience differed. The reform meant that one of the arenas in which labour unions and employers had collaborated successfully was more or less dismantled.

We would stress that the school reform was adopted at a time when industrial relations were rapidly deteriorating and when the solidarity wage policy meant that there was restricted scope for firms to use wages to induce young people to participate in vocational education. In contrast to several other countries, where the renegotiation of the skill system was the outcome of changes in economic and political structures, the transition to the statist system took place at the very beginning of the critical juncture. In fact, it can be seen as a precursor of increased political interfer-

85 Cf. Hall and Thelen (2009).

86 Busemeyer and Trampusch (2012). 
ence that reached other parts of the labour market in the 1970s. The 1960s (but not the 1970s) can certainly be characterised as a critical juncture in the formation of the Swedish skill system, but the preceding development and the radical outcome suggest that the long-term processes which set the stage for renegotiations are complex and even surprising. A thorough understanding of the changing nature of industrial relations rather than the preoccupation with political processes characteristic of most previous research is crucial in solving the enigma of the transformation of the skill formation system in Sweden. 


\section{References \\ Archival sources}

Hantverkarorganisationens kongresser: Anteckningar från SHO årsmöte (1925), Arkivbeteckning NAD: SE/RA/730338/A3.

Skogliga gymnasieutbildningen 1970-talet, 1966-1995, F1:3, Skogsbrukets yrkesutbildningsnämnd (SYN), Centrum för näringslivshistoria. Arkivbeteckning NAD: SE/CFN/SLA_26-1.

Teknikföretagen, F12a, vol. 52. Särskilda utredningar, "Uppgift på antal arbetare, yrkesarbetare resp. lärlingar vid verkstäder anslutna till Sveriges Verkstadsförening åren 1925-1947." Arkivbeteckning NAD: SE/CFN/TKF_1.

Utbildningsverksamheten vid Kockums, 1943-1957, F20:3, Kockums Mekaniska Verkstads AB, Malmö Stadsarkiv, Företagsarkiv, Handlingar gällande verkstadsskolan samt elevföreningen. Arkivbeteckning NAD: SE/MSA/00429/F/F20.

Årsrapporter från utbildningsavdelningen 1952-1966, F20:3, Kockums Mekaniska Verkstads AB, Malmö Stadsarkiv, Företagsarkiv, Handlingar gällande verkstadsskolan samt elevföreningen, Arkivbeteckning NAD: SE/MSA/00429/F/F20.

\section{Interviews}

Rauno Eberlund, ship construction apprentice 1966-1969, interviewed 30 March 2015.

Bengt Persson, electrician's apprentice 1955-1958, interviewed 6 March 2013.

Åke Sandström, electrician's apprentice 1966-1969, interviewed 30 March 2015.

\section{Printed sources and literature}

Adlercreutz, Axel. Kollektivavtalet: Studier över dess tillkomsthistoria. Lund: Gleerup, 1954.

Arbetsmarknadsorganisationernas yrkesutbildningskommitté. Betänkande med förslag till åtgärder för lärlingsutbildningens främjande. Stockholm: s.n., 1944.

Bengtsson, Berit. Kampen mot $\$ 23$ : Facklig makt vid anställning och avsked $i$ Sverige före 1940. Uppsala: Ekonomisk-historiska institutionen, Uppsala universitet, 2006.

Busemeyer, Marius and Christine Trampusch, eds. The Political Economy of Collective Skill Formation. Oxford: Oxford University Press, 2012. Oxford Scholarship Online, http://www.oxfordscholarship.com/view/10.1093/acprof:oso/9780199599431.001.0001/acprof-9780199599431.

Carmichael, Lorne. "Does Rising Productivity Explain Seniority Rules for Layoffs?" American Economic Review 73, no. 5 (1983), 1127-32.

Dobbins, Michael and Marius Busemeyer. "Socio-Economic Institutions, Organized Interests and Partisan Politics: The Development of Vocational Education in Denmark and Sweden." Socio-Economic Review 13, no. 2 (2015), 259-84.

Elvander, Nils. Lönepolitik och förhandlingssystem i Sverige. Uppsala: Nationalekonomiska institutionen, Uppsala universitet, 1992.

Hall, Peter A. and Kathleen Thelen. "Institutional Change in Varieties of Capitalism." Socio-Economic Review 7, no. 1 (2009), 7-34.

Hedman, Anders. I nationens och det praktiska livets tjänst: Det svenska yrkesskolesystemets tillkomst och utveckling 1918 till 1940. Umeå: Umeå universitet, 2001.

Hellstrand, Sandra. "Attempting Institutional Change: Swedish Apprenticeship, 1890-1917," Nordic Journal of Educational History 3, no. 2 (2016), 31-53. 
Håkansson, Peter. Ungdomsarbetslöshet: Om övergångsregimer, institutionell förändring och socialt kapital. Lund: Lund Studies in Economic History 55, 2011.

Kaufman, Bruce E. “The Original Industrial Relations Paradigm: Foundation for Revitalizing the Field." In New Directions in the Study of Work and Employment, edited by Charles J. Whelan, 31-47. Cheltenham: Elgar, 2008.

Kollektivaftal angående arbets- och löneförhållandena i Sverige 1907/1908. 1: Redogörelse för kollektivaftalens utbredning och hufvudsakliga innehåll. Stockholm: s.n., 1910.

Kollektivaftal angående arbets- och löneförhållandena i Sverige. 2. Stockholm: s.n., 1908.

Kungl. Skogsstyrelsen. Det enskilda skogsbruket. Stockholm: Kungl. Skogsstyrelsen, 1943.

Landsorganisationen i Sverige. Organisationskommittén. Fackföreningsrörelsen och den fulla sysselsättningen. Stockholm: s.n., 1951.

Landsorganisationen i Sverige. Strukturutredningen. Samordnad näringspolitik. Stockholm: LO, 1961.

Larsson, Hans A. Mot bättre vetande: En svensk skolhistoria. Stockholm: SNS Förlag, 2011.

Lundahl, Lisbeth. Efter svensk modell: LO, SAF och utbildningspolitiken 1944-90. Umeå: Boréa förlag, 1997.

Lundahl, Lisbeth. "Skilda framtidsvägar: Perspektiv på det tidiga 2000-talets gymnasiereform." Utbildning \& Demokrati 17, no. 1 (2008), 29-51.

Lundh Nilsson, Fay. Lönande lärande: Teknologisk förändring, yrkesskicklighet och lön $i$ svensk verkstadsindustri omkring 1900. Lund Studies in Economic History 40. Stockholm: Almqvist \& Wiksell, 2007.

Lundh Nilsson, Fay. "Sågverksindustrin och utbildningsfrågorna." In Sågad skog för välstånd: Den svenska sågverksindustrins historia 1850-2010, edited by Ronny Pettersson, 407-52. Stockholm: Kungliga Skogs- och Lantbruksakademien, 2015.

Lundh, Christer. Spelets regler: Institutioner och lönebildning på den svenska arbetsmarknaden 1850-2010. Stockholm: SNS, 2010.

Marklund, Sixten. Skolsverige 1950-1975, del 1-5, Stockholm: Liber Utbildningsförlag, 1980-87.

Nilsson, Anders. Yrkesutbildningen i Sverige 1850-1910. Uppsala: Föreningen för svensk undervisningshistoria, 2008.

Nilsson, Anders. "Lärlingsutbildning: Ett alternativ i yrkesutbildningen 1940-1970." In Yrkesutbildningens formering i Sverige 1940-1975, edited by Peter Håkansson and Anders Nilsson, 87-120. Lund: Nordic Academic Press, 2013.

Nilsson, Anders. "The Unknown Story: Vocational Education for Adults in Sweden 1918-1968." History of Education 43, no. 5 (2014), 615-34.

Nycander, Svante. Makten över arbetsmarknaden: Ett perspektiv på Sveriges 1900-tal. Stockholm: SNS förlag, 2002.

Olofsson, Jonas. Svensk yrkesutbildning: Vägval i internationell belysning. Stockholm: SNS Förlag, 2005.

Pettersson, Lars. "Därför valde Sverige en annan väg än Danmark. Historien bakom 1950-talets reformer av yrkesutbildningen." In Yrkesutbildningens formering i Sverige 1940-1975, edited by Peter Håkansson and Anders Nilsson, 155-84. Lund: Nordic Academic Press, 2013. 
Richardson, Gunnar. Svensk utbildningshistoria. Lund: Studentlitteratur, 1:a upplagan 1977, 7:e upplagan 2004.

SCB Promemorior 1974:5. Elever i obligatoriska skolor 1847-1962. Stockholm: Statistiska centralbyrån, 1974 .

SCB Promemorior 1984:2. Elever i skolor för yrkesutbildning 1844-1970. Örebro: Statistiska centralbyrån, 1984 .

Schön, Lennart. Sweden's Road to Modernity. Stockholm: SNS Förlag, 2010.

Sjöstedt, Sven-Ingvar. Skogsyrkesutbildning i Sverige. Karlshamn: Lagerblads, 1975.

Skogsindustriarbetaren: tidning för skogsbrukets samt sågverks- och pappersindustriernas arbetare, no. 23/24 (1939). Gävle.

Skogsindustriarbetaren: tidning för skogsbrukets samt sågverks- och pappersindustriernas arbetare, no. 34 (1939). Gävle.

Skogsindustriarbetaren: tidning för skogsbrukets samt sågverks- och pappersindustriernas arbetare, no. 2 (1940). Gävle.

Skogsindustriarbetaren: tidning för skogsbrukets samt sågverks- och pappersindustriernas arbetare, no. 1 (1943). Gävle.

Skogsindustriarbetaren: tidning för skogsbrukets samt sågverks- och pappersindustriernas arbetare, no. 25/26 (1943). Gävle.

Skogsindustriarbetaren: tidning för skogsbrukets samt sågverks- och pappersindustriernas arbetare, no. 1 (1947). Gävle.

Skogsindustriarbetaren: tidning för skogsbrukets samt sågverks- och pappersindustriernas arbetare, no. 32 (1947). Gävle.

Sociala Meddelanden, serie F, Statistiska Meddelanden 1911-1921.

SOU 1924:41. Utredning med förslag till lag om lärlingsväsendet $i$ vissa yrken. Stockholm: Norstedt \& söner, 1924.

SOU 1939:14. Rationaliseringsutredningens betänkande del II. Stockholm: Isaac Marcus boktryckeri-aktiebolag, 1939.

SOU 1947:32. Utredning med synpunkter på sågverksdriften $i$ Norrland och förslag angående inrättande av en central sågverksskola. Stockholm: Victor Pettersons bokindustriaktiebolag, 1947.

SOU 1954:11. Yrkesutbildningen. Stockholm: Ivar Häggströms boktryckeri AB, 1954.

SOU 1965:67. Skoglig yrkesutbildning: Utbildningsmål, utbildningsgång och huvudmannaskap. Stockholm: K. L. Beckmans tryckeri AB, 1965.

SOU 1966:3. Yrkesutbildningen. Lund: Håkan Ohlssons boktryckeri, 1966.

Statistisk Årsbok 1926, Stockholm: P.A. Norstedt \& söner, 1926.

Swenson, Peter A. Capitalists Against Markets: The Making of Labor Markets and Welfare States in the United States and Sweden. New York: Oxford University Press, 2002.

Söderberg, Tom. Hantverkarna i genombrottsskedet 1870-1920. Stockholm: Haglund \& Ericson, 1965.

Thelen, Kathleen. How Institutions Evolve: The Political Economy of Skills in Germany, Britain, the United States, and Japan. Cambridge: Cambridge University Press, 2004.

Thelen, Kathleen and Marius R. Busemeyer. "Institutional Change in German Vocational Training: From Collectivism toward Segmentalism.” In The Political Economy of Collective Skill Formation, edited by Marius R. Busemeyer and Christine Trampusch, 1-34. Oxford: Oxford University Press, 2012. Oxford 
Scholarship Online, http://www.oxfordscholarship.com/view/10.1093/acprof:oso/9780199599431.001.0001/acprof-9780199599431.

Uhlén, Axel. Malmö tobaksarbetarefackförening 1883-1933: Minnesskrift. Malmö: 1933.

Underdånigt utlåtande och förslag till den lägre tekniska undervisningens ordnande. Örebro: Länstidningens tryckeri, 1912.

Webb, Sidney and Beatrice Webb. Industrial Democracy. London: Longmans, Green and Co., 1902.

Yokoyama, Etsuo and Anders Nilsson. "Company-Based Vocational Education and Training: Case Studies of Shipbuilding Industries in Japan and Sweden." Essays in Economic \& Business History 34 (2016), 136-64.

Yrkesundervisningen åren 1921-1922. Stockholm: Kungl. Skolöverstyrelsen, 1923.

Wallis, Patrick. "Apprenticeship and Training in Premodern England." Journal of Economic History 68, no. 3 (2008), 832-61. 